\title{
EFEKTIVITAS MODEL MENULIS KOLABORASI DENGAN MEDIA BIG BOOK TERHADAP KETERAMPILAN MENULIS KREATIF
}

\author{
Krisna Anggraeni \\ krisnaanggraeni24@gmail.com \\ Universitas Majalengka
}

\begin{abstract}
ABSTRAK
Penelitian ini dilatarbelakangi oleh rendahnya keterampilan menulis kreatif di sekolah dasar. Tujuan penelitian ini adalah untuk mendeskripsikan keefektifan model menulis kolaborasi dengan media Big Book terhadap keterampilan menulis kreatif di sekolah dasar. Metode yang digunakan dalam penelitian ini adalah eksperimen kuasi dengan desain the nonrandomized control group, pratest-posttest. Desain penelitian ini menggunakan dua kelompok yaitu kelas eksperimen dan kelas kontrol. Pada kelas eksperimen diberikan perlakuan menggunakan model menulis kolaborasi dengan media Big Book, sedangkan pada kelas kontrol menggunakan metode konvensional yaitu pemberian tugas menulis. Subyek dalam penelitian ini adalah seluruh siswa kelas III SDN 1 Kalikajar Kabupaten Purbalingga Tahun Pelajaran 2014/2015 yang berjumlah 42 siswa yang terdiri dari dua kelas yaitu kelas III A dan III B yang dipilih dengan teknik purposive sampling. Hasil analisis data menunjukkan adanya perbedaan keterampilan menulis kreatif antara kedua kelas. Pada kelas kontrol yang menggunakan metode konvensional cenderung tidak mengalami peningkatan yang signifikan, sedangkan pada pascaperlakuan kelas eksperimen terjadi peningkatan keterampilan menulis kreatif. Berdasarkan hasil analisis data pada kelas eksperimen, nilai rata-rata keterampilan menulis kreatif saat prates 65 pascaperlakuan menjadi 92, terjadi peningkatan sebesar $41 \%$. Hasil analisis data tersebut mengindikasikan bahwa model menulis kolaborasi dengan Big Book efektif digunakan untuk meningkatkan keterampilan menulis kreatif.
\end{abstract}

Kata kunci : model menulis kolaborasi, Big Book, keterampilan menulis kreatif 


\section{Pendahuluan}

Ada empat aspek keterampilan berbahasa yaitu mendengarkan, berbicara, membaca dan menulis. Iskandarwassid dan Sunendar (2011, hlm 248) menjelaskan bahwa menulis adalah keterampilan berbahasa yang paling akhir dikuasai setelah keterampilan mendengarkan, berbicara, dan membaca. Seperti halnya berbicara, menulis merupakan usaha untuk mengungkapkan pikiran dan perasaan yang ada pada diri seorang pemakai bahasa. Perbedaannya terletak pada cara yang digunakan untuk mengungkapkannya. Pikiran dan perasaan dalam berbicara diungkapkan secara lisan, sedangkan dalam menulis dilakukan secara tertulis.

Dalam Buku Sumber untuk Dosen LPTK (2014, hlm. 147) dijelaskan bahwa:

Menulis bukan hanya sekedar menggambar huruf atau menyalin, tetapi lebih dari itu menulis merupakan keterampilan berbahasa dalam mengemukakan pikiran dan menyampaikan perasaan melalui bahasa tulis. Menulis bukan hanya cepatnya menulis huruf-huruf, tetapi yang lebih utama adalah menyampaikan pokok-pokok pikiran, ide, gagasan, intuisi hati secara teratur yang membutuhkan penghayatan dan mengandung nilai estetika.

Munandar (1999, hlm. 39) menjelaskan bahwa kreativitas di samping bermakna baik untuk pengembangan diri maupun untuk pembangunan masyarakat, juga merupakan salah satu kebutuhan pokok manusia, yaitu kebutuhan akan perwujudan diri sebagai salah satu kebutuhan paling tinggi bagi manusia. Menulis kreatif adalah menulis yang ditujukan untuk menyampaikan ide, perasaan, dan emosi bukan sekedar menyampaikan informasi saja. Pada pembelajaran menulis kreatif di sekolah dasar, difokuskan pada menulis karya fiksi seperti menulis cerita berdasarkan catatan harian, berdasarkan foto dan gambar, atau menulis puisi berdasarkan diksi. Oleh sebab itu, diperlukan latihan, peghayatan dan pengalaman untuk mengembangkan keterampilan menulis kreatif siswa.

Pentingnya kemampuan menulis kreatif di sekolah dasar belum diimbangi dengan hasil menulis kreatif yang baik. Pada penelitian yang dilakukan Hans Jallen dalam Supriadi (1994: 85) menyimpulkan bahwa tingkat kreativitas anak-anak Indonesia berada pada peringkat yang rendah. Tingkat kreativitas anak-anak Indonesia terendah di antara anak-anak usianya dari 8 negara lainnya berturut-turut dari yang tertinggi sampai yang terendah rata-rata skor tesnya adalah Filipina, Amerika Serikat, Inggris, Jerman, India, RRC, Kamerun, Zulu, dan terakhir Indonesia. Penyebab rendahnya kreativitas anak-anak Indonesia adalah lingkungan yang kurang menunjang untuk mengekspresikan kreativitasnya khususnya di lingkungan keluarga dan sekolah.

Faktor lain penyebab rendahnya keterampilan menulis siswa menurut Abidin (2013, hlm. 191) adalah kecenderungan guru yang lebih mengutamakan tata bahasa dalam menulis dibanding dengan bagaimana mengemukakan gagasan dalam menulis. Hal ini menyebabkan siswa menjadi mampu bertata bahasa dengan baik namun isi tulisan kurang berbobot.

Hal ini disebabkan karena beberapa masalah di dalam menulis, di antaranya adalah: (1) pelajaran bahasa Indonesia diangap pelajaran yang membosankan, (2) pengajaran bahasa Indonesia hanya bersifat monoton kurang variasi, (3) pelajaran menulis adalah pelajaran yang diangap susah dan, (4) pengajaran bahasa Indonesia lebih bersifat formal dan beracuan untuk mengejar materi dari buku paket. Tidak adanya antusiasme yang tinggi, telah membuat bahasa Indonesia menjadi pelajaran yang kalah penting dibanding 
dengan pelajaran lain. Minat siswa baik yang menyangkut minat menulis, maupun minat untuk mengikuti pelajaran bahasa Indonesia semakin tampak menurun.

Faktor penyebab rendahnya kemampuan menulis kreatif siswa meliputi faktor internal dan eksternal. Faktor penyebab internal adalah siswa cenderung kurang dapat berimajinasi, mengungkapkan ide, dan kemudian menuangkan kata ke dalam bentuk tulisan, siswa belum mampu merangkai kata-kata menjadi kalimat dan menyusunnya ke dalam tulisan yang utuh, serta siswa juga kurang memperhatikan ejaan dan tanda baca dalam menulis. Sementara faktor penyebab eksternal adalah suasana yang tindak kondusif dalam kelas, karena kurangnya media pembelajaran yang merangsang siswa untuk aktif dalam pembelajaran.

Abidin (2012: 204) mendefinisikan model menulis kaloborasi sebagai "model pembelajaran menulis yang memanfaatkan pengalaman penyusunan karangan secara bersama-sama sebagai dasar bagi penyusunan karangan secara mandiri". Penggunaan model menulis kolaborasi bertujuan memberikan pengalaman menulis bagi siswa secara bersama-sama. Dengan menulis bersama-sama, siswa akan mendapatkan banyak ide dan gagasan terkait tulisannya, sehingga diharapkan selanjutnya dapat menulis secara mandiri

Salah satu media visual yang dapat digunakan dalam pembelajaran menulis adalah Big Book atau buku besar. Big Book merupakan buku cerita yang berkarakteristik khusus yang dibesarkan, baik teks maupun gambarnya, sehingga memungkinkan terjadinya kegiatan membaca bersama antara guru dan murid. Big Book dapat menjadi media menulis kreatif melalui kegiatan membaca bersama dapat pula menjadi media yang baik karena memungkinkan siswa secara bersama-sama dengan bekerja sama memberi makna pada tulisan di dalamnya.

Berdasarkan hasil prasurvei terhadap subjek penelitian mengidentifikasi bahwa pembelajaran membaca di kelas III sekolah dasar tersebut belum terlaksana dengan baik. Hal ini dapat dilihat dari kurangnya kreativitas dalam pembelajan menulis dan kemampuan siswa memahami wacana yang belum baik. Kelemahan ini disebabkan berbagai faktor di antaranya adalah kurangnya minat menulis siswa, metode pembelajaran yang belum mengembangkan kreativitas siswa, media pembelajaran yang belum memfasilitasi siswa dalam kegiatan menulis kreatif, dan tindakan guru kelas dalam pembelajaran yang belum dikembangkan.

Meninjau permasalahan dalam pembelajaran menulis tersebut, maka dilakukanlah penelitian untuk meningkatkan keterampilan menulis kreatif di sekolah dasar. Penelitian ini berfokus pada model menulis kolaborasi dengan Big Book terhadap keterampilan menulis kreatif dengan subjek siswa kelas III sekolah dasar.

\section{Rumusan Masalah}

Rumusan masalah utama dalam penelitian ini adalah "apakah model menulis kolaborasi dengan media Big Book efektif untuk meningkatkan keterampilan menulis kreatif di sekolah dasar?".

\section{Tujuan Penelitian}

Tujuan utama dalam penelitian ini adalah untuk mengetahui keefektifan model menulis kolaborasi dengan media Big Book untuk meningkatkan keterampilan menulis kreatif di sekolah dasar.

\section{Manfaat Penelitian}

Secara teoritis, penelitian ini diharapkan dapat bermanfaat dalam menemukan model dan media pembelajaran yang efektif dalam pembelajaran menulis kreatif. Secara praktis, diharapkan penelitian ini dapat membantu guru mengembangkan pembelajaran menulis dan meningkatkan hasil belajar menulis kreatif siswa. 


\section{Keterampilan Menulis Kreatif}

Sokolik mengemukakan bahwa "writing is a combination of process and product". Sedangkan Olson berpendapat bahwa "the concept that writing is a process is very useful to young writers" (Linse, 2005: 98). Dapat disimpulkan bahwa konsep menulis merupakan perpaduan antara proses dan hasil. Selanjutnya Yunus, dkk (2009, hlm 1.3) mengemukakan bahwa dalam menulis setidaknya terdapat empat unsur yang terlibat yaitu: a) penulis sebagai penyampai pesan, b) pesan atau sesuatu yang disampaikan penulis, c) saluran atau medium berupa lambang-lambang bahasa tulis seperti huruf dan tanda baca, d) penerima pesan, yaitu pembaca, sebagai penerima pesan yang disampaikan oleh penulis.

Tujuan pembelajaran menulis sesuai dengan kurikulum 2006 adalah sebagai berikut: (a) mampu mengungkapkan ide dan gagasan, (b) siswa dapat memahami materi dari berbagi segi, bentuk, makna dan fungsi, (c) siswa memiliki kemampuan dalam menggunakan materi yang diajarkan untuk meningkatkan kemampuan intelektualnya, kematangan emosional dan kematangan sosial serta, dan (d) siswa dapat mengingat materi dan memudahkannya dalam mempelajarinnya untuk meningkatkan ilmu pengetahuan dan wawasan. Dapat disimpulkan tujuan pembelajaran menulis di Sekolah Dasar adalah agar siswa mampu mengekspresikan berbagai pikiran, gagasan, pendapat dan perasaannya.

Byrne (1988, hlm. 130) menjelaskan ada dua hal yang harus diperhatian guru ketika mengajarkan menulis pada siswa kelas rendah yaitu "... First, writing must not impair oral fluency... Secondly, we should not try to teach aspects of the written language which learners at this age cannot be expected to understand and cope with." Hal ini berarti menulis tidak menghalangi kelancaran lisan dan guru tidak seharusnya mengajarkan bahasa tulis yang belum saatnya dipelajari siswa, seperti hubungan antar kalimat.

Menulis merupakan kegiatan produktif dalam menghasilkan sebuah tulisan yang diperoleh dari proses berpikir dalam mengungkapkan gagasan, pikiran, dan perasaan kepada orang lain atau dirinya sendiri ke dalam bentuk bahasa tertulis yang dapat dimengerti dan layak dibaca. Sementara itu, kemampuan berpikir kreatif menurut Torrance dalam Jordan (2002, hlm. 31) adalah kemampuan seseorang untuk menuangkan gagasan secara lancar, menciptakan sesuatu yang tidak sama dengan orang lain, sesuatu yang baru, atau hasil modifikasi dari sesuatu yang sudah ada, merincikan suatu objek kajian, dan memberikan pengembangan secara detail. Dapat disimpulkan bahwa menulis kreatif adalah kegiatan mengungkapakn gagasan, pikiran dan perasaan secara lancar dengan menciptakan sesuatu yang tidak sama, baru, atau hasil modifikasi dari sesuatu yang telah ada dalam bentuk bahasa tertulis yang dapat dimengerti dan layak dibaca.

Menurut Sil.org dalam Buku Sumber untuk Dosen LPTK (2014, hlm. 148) mengemukakan bahwa "Creative writing is writing that expresses the writer's thoughts and feelings in an imaginative, often unique, and poetic way", sementara Don DeLillo menjelaskan:

Writing is a form of personal freedom. It frees us from the mass identity we see all around us. In the end, writers will write not to be outlaw heroes of some underculture but mainly to save themselves, to survive as individuals.

Menurut pernyataan di atas, menulis kreatif adalah tulisan yang berisi pikiran dan perasaan penulis dengan menggunakan imajinasinya, unik, dan ditulis secara puitis.

Fokus pembahasan menulis kreatif pada pengembangan menulis karya fiksi anak-anak, seperti menulis cerita anak berdasarkan refleksi catatan harian, berdasarkan gambar dan foto, serta menulis 
puisi anak berdasarkan model pembelajaran "urai-sambung diksi".

\section{Model Menulis Kolaborasi dengan Media Big Book}

Model menulis kolaborasi diawali dengan kegiatan menulis secara bersamasama antar siswa dalam kelas dan diakhiri dengan menulis secara mandiri, tujuan dari kegiatan menulis bersama adalah agar siswa yang telah menguasai keterampilan menulis dapat mengajari siswa yang lain dan antar siswa dapat saling berbagi ide-ide kreatif dalam menulis.

Model menulis kolaborasi dilaksanakan dalam tiga tahapan. Tahap pertama, tahap pramenulis. Pada tahap pramenulis ini siswa menentukan topik, mengumpulkan informasi, menentukan maksud dan tujuan penulisan serta membuat kerangka tulisan secara berkelompok.

Tahap kedua, tahap menulis. Tahap menulis diawali dengan menulis draf kolaborasi dengan cara siswa pertama menulis kalimat pertama, diikuti siswa kedua menulis kalimat kedua seterusnya hingga seluruh anggota kelompok menuliskan kalimatnya menjadi satu paragraf. Dapat pula dilakukan dengan setiap anggota kelompok membuat satu paragraf. Selanjutnya hasil tulisan didiskusikan untuk diperbaiki dan disunting. Hasil tulisan kelompok kemudian dikonferensikan (dibacakan di depan kelas) sehingga hasil tulisan dapat dikoreksi dan diberi masukan oleh kelompok lain maupun oleh guru. Tahap akhir menulis adalah siswa menulis mandiri.

Tahap ketiga, tahap pascamenulis. Tahap ini dapat dilakukan dengan proses penyuntingan di mana hasil tulisan siswa dikoreksi siswa lain atau guru. Selanjutnya, hasil tulisan siswa dipublikasikan, misalnya dengan dipajang di mading atau koran sekolah.

Steinberg (dalam Tampubolon, 1993) mengatakan bahwa materi bacaan harus terdiri atas kata-kata, frasa-frasa, dan kalimat-kalimat yang bermakna yang berasal dari pengalaman anak atau pernah dialami anak (hlm. 43). Salah satu cara memberikan pengalaman bagi anak adalah dengan menunjukkannya melalui visual misalnya gambar. Gambar dalam Big Book akan memberi skemata pengetahuan tentang bahasa lisan gambar itu kepada anak. Sehingga pengetahuan yang diperoleh masuk dalam memori jangka panjang.

Dalam Buku Sumber untuk Dosen LPTK (2014, hlm. 42) disebutkan bahwa Big Book adalah buku bacaan yang memiliki ukuran, tulisan, dan gambar yang besar. Ukuran Big Book bisa beragam, misalnya ukuran A3, A4, A5, atau seukuran koran. Ukuran Big Book harus mempertimbangkan segi keterbacaan seluruh siswa di kelas. Lynch (1996) melanjutkan bahwa Big Book yang di cetak besar dengan ilustrasi warna warni memungkinkan seluruh kelas untuk berbagi cerita yang baik. Selain itu, ketika digunakan dalam kelompok kecil (sekitar delapan anak), Big Book memperkaya perkembangan bahasa lisan melalui membaca permodelan.

Penggunaan media Big Book dalam pembelajaran model menulis kolaborasi bertujuan agar siswa dapat mengasimilasi pemahaman visual dari kegiatan membaca bersama sehingga dapat mengembangkan ide, informasi dan gagasan ketika menulis bersama maupun mandiri. 


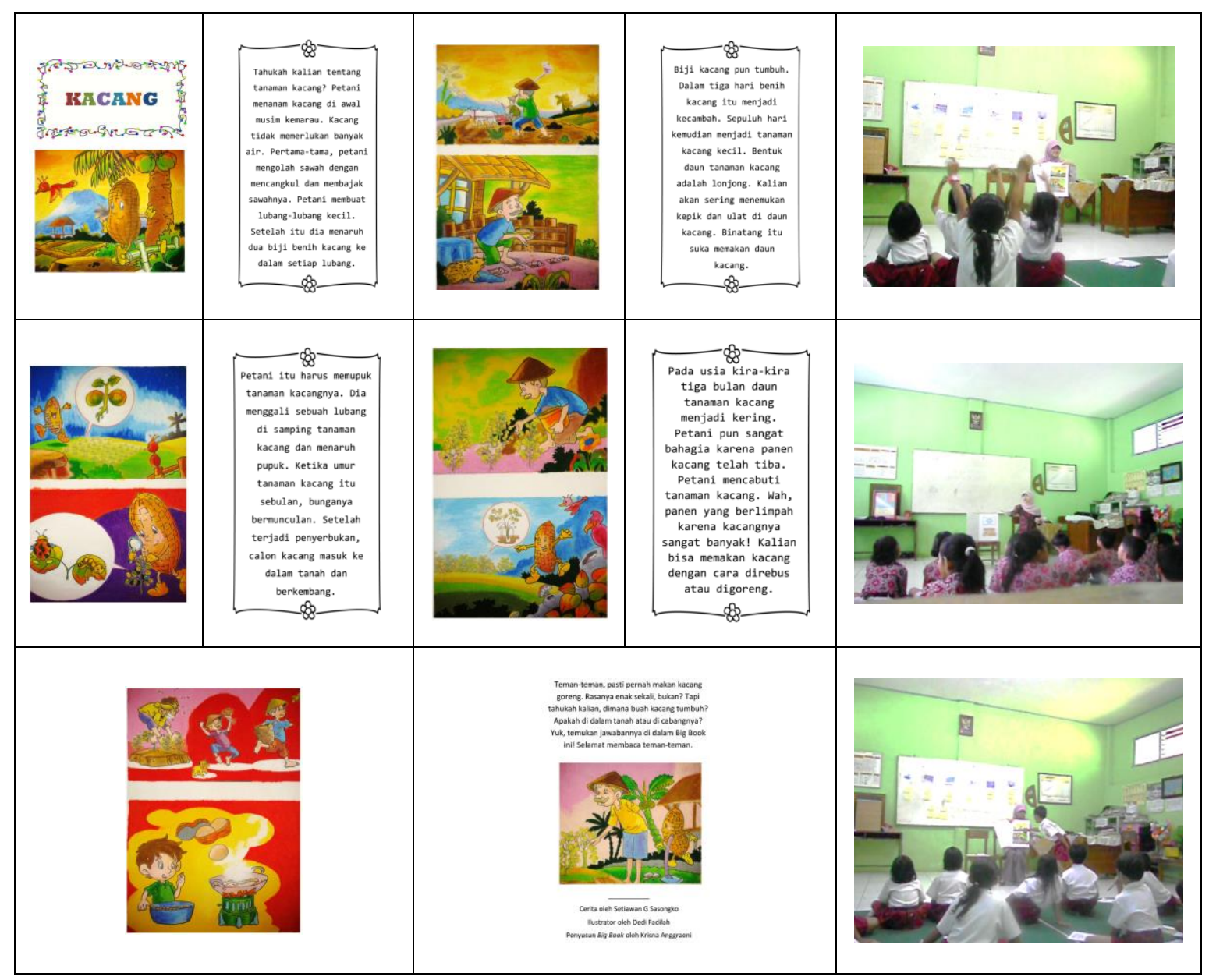

Gambar 1

Gambar contoh Big Book dengan judul "Kacang" dan cara penggunaannya

\section{Metode Penelitian}

Tujuan dari penelitian ini adalah menghasilkan metode dan media pembelajaran yang teruji keefektifannya untuk diterapkan pada proses pembelajaran menulis kreatif di sekolah dasar. Untuk mencapai hal tersebut maka digunakan metode penelitian eksperimen kuasi dengan desain the nonrandomized control group, pratest-posttest. Ary dkk (2010, hlm. 316) menyebut bahwa the nonrandomized control group, pratest-posttest adalah salah satu desain yang paling banyak digunakan dalam metode penelitian eksperimen kuasi dalam pendidikan.
Tabel 1

Desain Kuasi Eksperimen

\begin{tabular}{cccc}
\hline Kelompok & Pra-tes & $\begin{array}{c}\text { Variabel } \\
\text { bebas }\end{array}$ & Pasca-tes \\
\hline Eksperimen & $\mathrm{O}_{1}$ & $\mathrm{X}_{1}$ & $\mathrm{O}_{2}$ \\
\hline Kontrol & $\mathrm{O}_{3}$ & $\mathrm{X}_{2}$ & $\mathrm{O}_{4}$ \\
\hline
\end{tabular}

(diadaptasi dari Ary dkk, 2010:316)

Keterangan:

$\mathrm{O}_{1}=$ Tes awal pada kelompok eksperimen

$\mathrm{O}_{2}=$ Tes akhir pada kelompok eksperimen

$\mathrm{O}_{3}=$ Tes awal pada kelompok kontol

$\mathrm{O}_{4}=$ Tes akhir pada kelompok kontrol

$\mathrm{X}_{1}=$ Pemberian perlakukan, model kolaborasi dengan Big Book

$\mathrm{X}_{2}=$ Pemberian perlakuan, metode konvensional 
Peneliti dalam desain ini menentukan kelompok eksperimen $\left(\mathrm{O}_{1}\right)$ dan kelompok kontrol $\left(\mathrm{O}_{2}\right)$, melakukan prates untuk kedua kelompok dengan maksud untuk mengetahui homogenitas dan normalitas kedua kelompok, melakukan perlakuan eksperimen (X) yang dalam penelitian ini adalah model menulis kolaborasi dengan media Big Book hanya dengan kelompok eksperimen $\left(\mathrm{O}_{1}\right)$, dan kemudian melakukan pascates untuk mengukur perbedaan antara dua kelompok. Desain penelitian digambarkan dalam tabel sebagai berikut.

Pengambilan sampel pada penelitian ini menggunakan teknik purposive sampling. Menurut Bungin (2011, hlm. 125) teknik sampling ini "digunakan pada penelitian-penelitian yang lebih mengutamakan tujuan penelitian daripada sifat populasi dalam menentukan sampel penelitian", sehingga data yang diperoleh lebih representatif. Penelitian ini menggunakan subjek siswa sekolah dasar, sehingga dipilihlah SDN 1 Kalikajar Kabupaten Purbalingga dalam penelitian ini dengan alasan dari 47 sekolah dasar di Kecamatan Kaligondang Kabupaten Purbalingga hanya SDN 1 Kalikajar yang memiliki kelas III paralel A dan B. Selain itu, sekolah tersebut belum pernah melaksanakan pembelajaran menggunakan model menulis kolaborasi dengan Big Book.

Subyek dalam penelitian ini adalah seluruh siswa kelas III SDN 1 Kalikajar Kabupaten Purbalingga Tahun Pelajaran 2014/2015 yang berjumlah 42 siswa yang terdiri dari dua kelas yaitu kelas III A dan III B.

Nurgiyantoro

(2014:

423) menjelaskan:

Tes kemampuan menulis, sebagaimana halnya dengan tes kemampuan berbicara, cukup potensial untuk dijadikan tes yang bersifat pragmatik dan atau otentik...bahasa, hanya merupakan sarana, dan gagasan apa yang ingin dikomunikasikan pada hakikatnya lebih penting daripada sarana bahasa itu sendiri.

Keterampilan menulis kreatif dilihat berdasarkan dua aspek yaitu kemampuan menulis imajinatif berdasarkan gambar dan menulis puisi berdasarkan tokoh.

Tabel 2

Kisi-Kisi Menulis Kreatif

\begin{tabular}{|c|c|c|}
\hline Variabel & Indikator & Skor \\
\hline \multirow{5}{*}{$\begin{array}{c}\text { Menulis } \\
\text { imajinatif } \\
\text { berdasar- } \\
\text { kan gambar }\end{array}$} & $\begin{array}{c}\text { Kesesuaian isi dan judul } \\
\text { dengan gambar }\end{array}$ & 10 \\
\hline & $\begin{array}{l}\text { Pengembangan kalimat } \\
\text { dalam paragraf }\end{array}$ & 10 \\
\hline & $\begin{array}{c}\text { Pengembangan deskripsi } \\
\text { objek }\end{array}$ & 10 \\
\hline & Ejaan dan tanda baca & 10 \\
\hline & Pemilihan diksi & 10 \\
\hline \multicolumn{2}{|r|}{ Jumlah } & 50 \\
\hline \multirow{5}{*}{$\begin{array}{l}\text { Menulis } \\
\text { puisi } \\
\text { tentang } \\
\text { tokoh }\end{array}$} & Kelengkapan aspek puisi & 10 \\
\hline & Gaya bahasa & 10 \\
\hline & Pilihan kata atau diksi & 10 \\
\hline & Rima & 10 \\
\hline & Kejelasan hakikat puisi & 10 \\
\hline \multicolumn{2}{|r|}{ Jumlah } & 50 \\
\hline
\end{tabular}

Data penelitian diolah dengan dua cara yaitu dengan metode deskriptif dan metode statistik. Data penelitian berupa lembar observasi, hasil angket, dan hasil wawancara diolah dengan metode deskriptif, sementara data hasil tes tertulis diolah dengan metode statistik. Analisis metode statistik dilakukan dengan uji normalitas, uji homogenitas, uji hipotesis, dan uji gain dengan bantuan IBM SPSS Statictic 20.

\section{Hasil dan Pembahasan}

Data yang dianalisis dalam penelitian ini adalah skor prates, pascates dan $\mathrm{N}$-gain keterampilan menulis kreatif siswa kelas kontrol dan siswa kelas eksperimen. Skor prates menunjukkan skor sebelum perlakukan dan skor pascates menunjukkan skor setelah perlakukan dengan menggunakan model menulis kolaborasi dengan Big Book. Deskripsi data skor prates, pascates dan $\mathrm{N}$-gain keterampilan 
menulis kreatif disajikan dalam tabel berikut.

Tabel 4

Data Prates dan Pascates Kelas Eksperimen Dan Kontrol

\begin{tabular}{|c|c|c|c|c|c|}
\hline \multicolumn{2}{|c|}{ Kelas } & $\min$ & maks & $\begin{array}{l}\text { Rata } \\
\text {-rata }\end{array}$ & $\begin{array}{c}\text { Rata-rata } \\
N \text {-gain }\end{array}$ \\
\hline \multirow{2}{*}{$\begin{array}{l}\text { Eks- } \\
\text { peri- } \\
\text { men }\end{array}$} & Prates & 47 & 84 & 65 & \multirow{2}{*}{$\begin{array}{c}0.778 \\
\text { (tinggi) }\end{array}$} \\
\hline & $\begin{array}{l}\text { Pasca- } \\
\text { tes }\end{array}$ & 75 & 100 & 92 & \\
\hline \multirow{2}{*}{$\begin{array}{l}\text { Kon- } \\
\text { trol }\end{array}$} & Prates & 30 & 84 & 65 & \multirow{2}{*}{$\begin{array}{c}0.248 \\
\text { (rendah) }\end{array}$} \\
\hline & $\begin{array}{l}\text { Pasca- } \\
\text { tes }\end{array}$ & 35 & 92 & 74 & \\
\hline
\end{tabular}

Berdasarkan tabel di atas, pada keterampilan menulis kreatif diketahui bahwa kemampuan siswa sebelum perlakuan (prates) sama baik pada kelas eksperimen maupun kontrol yaitu rata-rata kelas 65. Namun, pasca perlakuan model menulis kolaborasi dengan Big Book pada kelas eksperimen, rata-rata berubah. Ratarata pascates kelas eksperimen mencapai 92 sedangkan kelas kontrol hanya 74. Mutu peningkatan juga dapat dilihat dari $N$-gain kedua kelas yang berbeda. $N$-gain pada kelas eksperimen mencapai 0.778 yang termasuk kategori tinggi, sedangkan $\mathrm{N}$-gain kelas kontrol hanya 0.248 yang termasuk kategori rendah.

Perbedaan data prates dan pascates kelas eksperimen dan kelas kontrol pada keterampilan menulis kreatif juga dapat dilihat pada Gambar. 2. Gambar menunjukkan bahwa pada kelas kontrol jarak grafik tidak terlalu jauh, karena $N$ gain kecil, sedangkan pada kelas eksperimen jarak grafik berjauhan, karena $N$-gain besar.

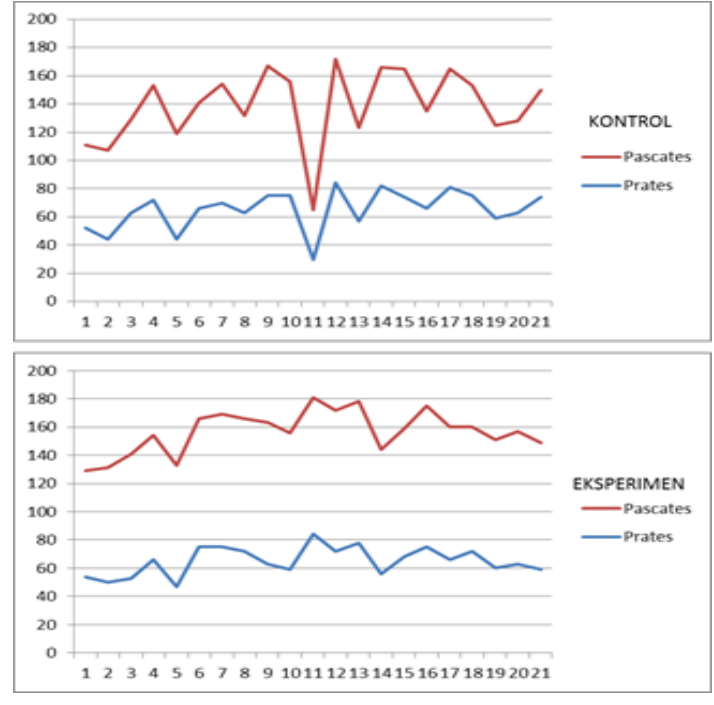

Gambar 2

Grafik Perbandingan Nilai Prates dan Pascates Kelas Eksperimen dan Kontrol

Untuk mengetahui mutu peningkatan keterampilan menulis kreatif menggunakan model menulis kolaborasi dengan Big Book, maka selanjutkan dilakukan perhitungan uji $N$-gain dengan hasil yang disajikan pada tabel 3 .

Deskripsi mutu peningkatan keterampilan menulis kreatif dapat dilakukan dengan analisis $\mathrm{N}$-gain $(\mathrm{g})$. Uji kesamaan rerata data $N$-gain menulis kreatif dilakukan menggunakan uji student ( $\mathrm{t}$ ) karena data normal dan homogen. Diketahui bahwa $t_{\text {hitung }}$ sebesar 10.034. Dikarenakan $t_{\text {hitung }} 10.034>t_{\text {tabel }} 2.021$ maka $\mathrm{H}_{0}$ ditolak dan $\mathrm{H}_{1}$ diterima. Dengan demikian, maka terdapat perbedaan $\mathrm{N}$-gain keterampilan menulis kreatif antara kelas eksperimen dengan kelas kontrol. Perbedaan tersebut dapat dilihat dari ratarata $N$-gain kelas eksperimen (0.779) dengan kategori tinggi yang berada di atas rata-rata $N$-gain kelas kontrol (0.252) dengan kategori rendah. 
Tabel 3

Hasil Uji $N$-gain Menulis Kreatif

\begin{tabular}{|l|l|l|l|l|}
\hline $\begin{array}{l}\text { Uji } \\
\text { Norma- } \\
\text { litas }\end{array}$ & $\begin{array}{l}\text { Ekspe } \\
\text { rimen }\end{array}$ & 0.122 & $<0.287$ & Normal \\
\hline $\begin{array}{l}\text { Uji } \\
\text { Norma- } \\
\text { litas }\end{array}$ & $\begin{array}{l}\text { Kon- } \\
\text { trol }\end{array}$ & 0.182 & $<0.287$ & Normal \\
\hline $\begin{array}{l}\text { Uji } \\
\text { Homogenitas }\end{array}$ & 1.082 & $<2.120$ & Homogen \\
\hline Uji t & 10.034 & $>2.021$ & $\begin{array}{l}\text { Terdapat } \\
\text { perbedaan } \\
\left(\mathrm{H}_{0}\right. \\
\text { positif })\end{array}$ \\
\hline
\end{tabular}

Berdasarkan hasil analisis data dapat diketahui bahwa model menulis kolaborasi dengan Big Book efektif dalam meningkatkan keterampilan menulis kreatif. Efektivitas ditunjukkan dengan peningkatan nilai prates dan pascates kelas eksperimen. Selain itu mutu peningkatan juga dapat ditunjukkan dari nilai gain yang tinggi.

Beberapa temuan yang peneliti dapatkan berdasarkan hasil analisis data dipaparkan sebagai berikut.

Pertama, penggunaan media Big Book dapat digunakan dalam kegiatan membaca bersama sehingga siswa mendapat pemahaman visual terhadap apa yang dibaca. Pemahaman visual ini membantu siswa untuk mengasimilasi pengalaman membacanya untuk mengembangkan kreativitas saat menulis. Hal ini disebabkan siswa sekolah dasar kelas III berada dalam tahap operasional konkret karena rata-rata usia mereka delapan tahun, maka pembelajaran di sekolah dasar kelas III harus dimulai dari hal yang kongkret ke hal yang abstrak.

Kedua, sesuai dengan apa yang disampaikan Tambubolon (1993: 68) bahwa pembelajaran bahasa harus menyenangkan. Pengalaman menulis bersama dengan metode kolaborasi yang menyenangkan, ditambah dengan Big Book, dapat menumbuhkan minat membaca dan menulis siswa. Diharapkan hal ini mampu menjadi kebiasaan bagi siswa untuk suka membaca dan menulis.
Ketiga, pembelajaran menggunakan model kolaborasi dengan Big Book juga sesuai dengan karakteristik pembelajaran bahasa yang whole language. Menurut Goodman (1992) salah satu karakteristik pembelajaran bahasa yang whole language adalah guru menerapkan 'scaffolding' dan 'collaboration'. Pembelajaran menulis di sekolah dasar dengan Big Book membantu anak membaca keseluruhan teks sebelum mereka menulis secara kolaborasi dan mandiri. Membaca bersama antara guru dengan siswa juga menunjukkan kolaborasi yang bermanfaat satu sama lain. Siswa yang belum pandai menulis akan dapat memiliki kepercayaan diri yang lebih untuk menulis.

\section{Simpulan}

Keterampilan menulis kreatif kelas eksperimen pascaperlakuan menggunakan model menulis kolaborasi dengan Big Book berbeda dengan kelas kontrol. Rata-rata nilai menulis kreatif kelas eksperimen lebih tinggi dibandingkan kelas kontrol. Secara empirik, model menulis kolaborasi dengan Big Book efektif dalam meningkatkan keterampilan menulis kreatif dengan taraf signifikansi kenaikan mencapai $41 \%$.

Keefektifan tersebut dipengaruhi oleh tahapan dalam penggunaan model menulis kolaborasi dengan Big Book yang mendukung dalam pembelajaran menulis kreatif. Aktivitas menulis bersama memfasilitasi siswa dengan keterampilan menulis yang belum baik untuk dibantu dengan temannya yang lain sehingga peran tutor sebaya dapat berjalan dengan baik. Selain itu, selama kegiatan menulis bersama siswa dapat saling berbagi ide, informasi, dan gagasan yang dapat meningkatkan kreativitas siswa.

\section{Daftar pustaka}
Abidin, Y. (2012). Pembelajaran bahasa berbasis pendidikan karakter. Bandung: Refika Aditama


Ary, D., Jacobs, L. C \& Sorensen, C. K. (2010). Introduction to research in education eighth edition. Wadsworth: Cengage Learning

Byrne, D. (1988). Teaching writing wkills new ed. England: Longman Group UK Limited

Bungin, B. 2011. Metodologi penelitian kuantitatif. Jakarta: Kencana.

Goodman, K.S. (1992). I didn't found whole language. The Reading Teacher, 46, hlm. 188-199

Iskandarwassid \& Sunendar, D. (2011). Strategi pembelajaran bahasa. Bandung: Rosdakarya

Linse, C. T. (2005). Practical English Language Teaching Young Learners. New York: McGraw Hill

Lynch, P. (1996). Using Big Books and predictable books. Canada: Scholastic Canada Ltd

Munandar, U. (1999). Kreativitas dan keberbakatan: Strategi mewujdukan potensi kreatif dan bakat. Jakarta: Gramedia
Nurgiyantoro, B. (2014). Penilaian pembelajaran bahasan berbasis kompetensi cetakan keenam. Yogyakarta: BPFE-Yogyakarta

Solchan dkk. (2009). Pendidikan bahasa indonesia di SD cet. 7. Jakarta: Universitas Terbuka

Supriadi, D. (1994). Kreativitas, kebudayaan dan perkembangan IPTEK. Bandung: Alfabeta

Supriyadi. (2006). Pembelajaran sastra yang apresiatif dan integratif di sekolah dasar. Direktorat Pendidikan Nasional, Direktorat Jenderal Pendidikan Tinggi, Direktorat Ketenagaan

Tampubolon. (1993). Mengembangkan minat dan kebiasaan membaca pada anak. Bandung: Angkasa

Tanpa-nama. (2014). Buku sumber untuk dosen LPTK: pembelajaran literasi kelas awal LPTK. Bandung: USAID

Yunus M, dkk. (2009). Menulis 1. Jakarta: Universitas 